\title{
Erratum to: Linear Elastic Solutions for Slotted Plates
}

\author{
David J. Unger
}

Published online: 21 October 2011

(C) Springer Science+Business Media B.V. 2011

\section{Erratum to: J Elast}

\section{DOI 10.1007/s10659-011-9356-Z}

Corrections 1-3: In three equation lines before the numbers: (2.10), (3.11), and (4.5), the end of the equations

$$
\ldots, 0 \leq \psi \leq E\left(m_{1}\right) \quad \text { should read instead } \quad \ldots, 0 \leq \psi \leq K\left(m_{1}\right),
$$

that is, $E\left(m_{1}\right)$ should be replaced by $K\left(m_{1}\right)$.

Corrections 4-5: In the paragraph before equation line (2.10)

$$
\phi=E(m) / 2 \text { should read instead } \phi=K(m) / 2,
$$

that is, $E(m)$ should be replaced by $K(m)$. Similarly, in the paragraph before line (3.11)

$$
\phi=E(m) / 2 \text { should read instead } \phi=K(m) / 2 .
$$

The online version of the original article can be found under doi:10.1007/s10659-011-9356-z. 